Wave energy fluxes and multidecadal shoreline changes in two coastal embayments in Denmark

Kabuth, Alina Kristin; Kroon, Aart

Published in:

Coastal Dynamics 2013

Publication date:

2013

Document version

Publisher's PDF, also known as Version of record

Citation for published version (APA):

Kabuth, A. K., \& Kroon, A. (2013). Wave energy fluxes and multidecadal shoreline changes in two coastal embayments in Denmark. In Coastal Dynamics 2013: 7 International Conference on Coastal Dynamics (pp. 905-916) 


\title{
WAVE ENERGY FLUXES AND MULTI-DECADAL SHORELINE CHANGES IN TWO COASTAL EMBAYMENTS IN DENMARK
}

\author{
Alina K. Kabuth ${ }^{1}$ and Aart Kroon ${ }^{2}$
}

\begin{abstract}
Spatial patterns of multi-decadal shoreline changes in two microtidal, low-energetic embayments of southern Sealand, Denmark, were explained by wave energy flux distributions. The first site is a barrier system attached to a moraine island. The system is characterized by an alignment of the barrier through alongshore alternating directions of barrier spit progradation and cross-shore translation of small barrier islands in a bidirectional wave field. The other site consists of a recurved spit adjacent to a cliff coast. This spit experiences shoreline rotation through proximal erosion and distal lateral accretion in a unidirectional wave climate. Multi-decadal shoreline changes were coupled with a slope-based morphological coastal classification and with the alongshore variability of the directional distribution of wave energy fluxes to outline potential sediment sources and sinks.
\end{abstract}

Keywords Shoreline change, Wave energy flux, Barrier island, Spit

\section{Introduction}

Barrier islands and spits are typical morphological features for the inner Danish waters. These shoreline straightening features are both swash-aligned and current-aligned and develop in topographic depressions between moraine ridges. Kroon et al. (in press) concluded in a study of a barrier system in southern Sealand that inlet breaching was connected with high-energy waves coinciding with high water levels, and that subsequent closure of inlets and shoreline alignment of the barrier are forced by alongshore wave-driven processes in moderate wave energy conditions. The offshore wave angle, the orientation of the shoreline and bathymetric contours affect the angle of wave incidence and resulting currents at the shore, while the shoreforming substrate affects the availability of sediment sources. We compare two embayments that are morphologically characterized by barrier islands and spits attached to glacial bluffs, under similar low-energy wave climates and with similar tidal ranges. However, the wave fields differ: one embayment lies in a dominantly unidirectional wave field while the other lies in a dominantly bidirectional wave field.

Morphodynamic characterizations of beaches in microtidal environments in Australia and the UK distinguish shores by the dimensionless fall velocity (Wright and Short, 1984), the absolute wave energy flux (Scott et al., 2011) and the beach morphology in relation to shelter through beach aspect and reefs (Hegge et al., 1996). However, traditional morphodynamic characterizations aim at sediment properties, beach slopes and wave height without regard to alongshore variations in beach morphology and the influence of alongshore drift (Anthony, 1998). In the two presented low-energetic, micro-tidal study areas, we observed large alongshore variability of shoreline evolution within a few kilometers in the same embayment. Failing the distinction of those diverse environments of shoreline evolution by traditional morphodynamic parameters, we apply a wave energy flux parameter with inherent consideration of the shoreline orientation. We applied a slope-based morphological shoreline characterization and interpreted Digital Elevation Models (DEM) and aerial photographs to assess potential sediment sources.

\footnotetext{
${ }^{1}$ Department of Geosciences and Natural Resource Management. University of Copenhagen, Øster Voldgade 10, 1350 Copenhagen K, Denmark, akk@geo.ku.dk

${ }^{2}$ Department of Geosciences and Natural Resource Management. University of Copenhagen, Øster Voldgade 10, 1350 Copenhagen K,

Denmark, ak@geo.ku.dk
} 


\section{Regional setting}

The island of Sealand is surrounded by the Baltic Sea in the east, the Kattegat in the north, and the inner Danish straits in the west and the south. Moraine deposits of Weichsel origin establish the relief forming intricate inner coastlines in southern Sealand. A characteristic double-coast developed here in the Holocene (Schou, 1945). The evolution of barriers is simplifying and consequently straightening the exposed shoreline. Under storm conditions, inlets between the barriers breach and are activated for water exchange between Karrebæksminde Bay and the lagoons of Basnæs Nor and Holsteinborg Nor. Regular wave action closes inlets through onshore transport of sediments and their alongshore wave-driven redistribution between shoals and inlets (Brøndum, 1972; Kroon et al., in press). The embayments at Sealand's east coasts are separated by headlands of till, and chalk or lime cliffs pressed up by Weichselian glaciers. Throughout the Holocene, sediment reworking smoothed the paraglacial relief, eroding headland cliffs and accreting marine foreland in the sheltered embayments in the form of barriers and spits.

The shores at both study sites are natural and unprotected by coastal structures or nourishment schemes, which makes them favorable for an analysis of natural coastal morphodynamics.

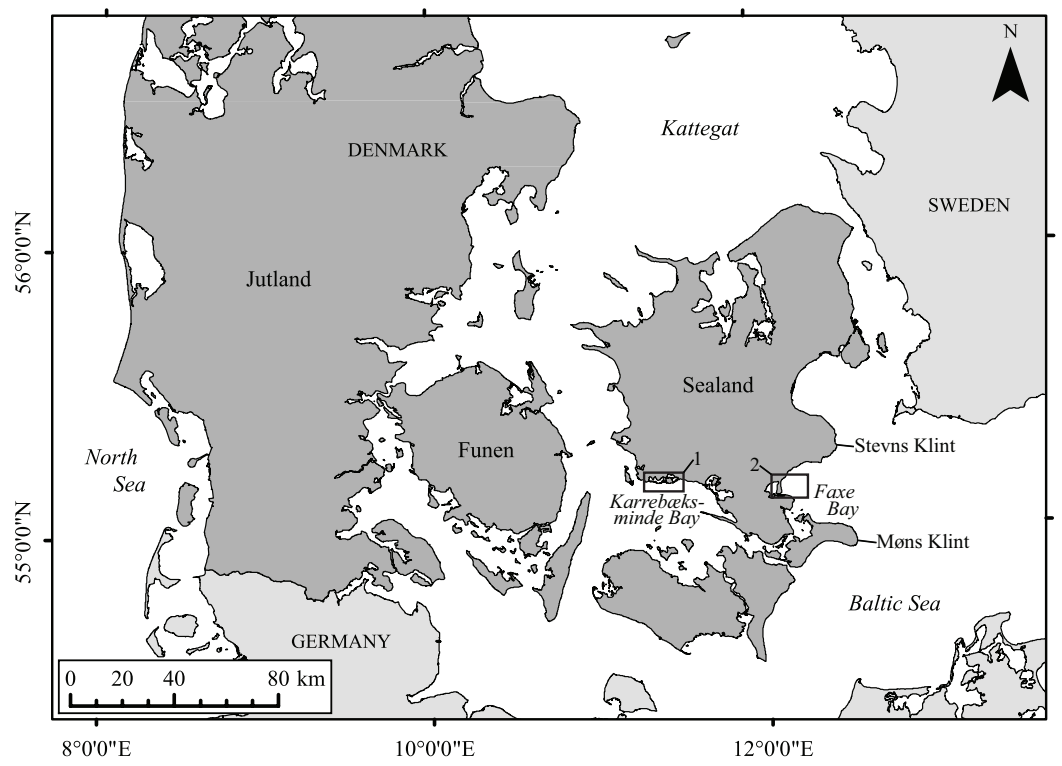

Figure 1: Overview map with study sites: Box 1: Study site in Karrebæksminde Bay; Box 2: Study site in Faxe Bay

\subsection{Geomorphology}

The barrier islands in Karrebæksminde Bay (Fig.1, Box 1) are attached to moraine islands and headlands and protect the lagoons that fringe the embayments along the inner coastlines, Basnæs Nor and Holsteinborg Nor. The bathymetry around Karrebæksminde Bay is characterized by stone reefs formed in moraine deposits (Støttrup, 1999). A NW-SE oriented moraine ridge borders Karrebæksminde Bay in the SW. The moraine ridge establishes reefs emerging up to sea level, sheltering the shores of the Karrebæksminde barrier system toward S. The inshore profile at the Holsteinborg Nor barrier is incised by a channel down to $-5 \mathrm{~m}$ (Fig. 2a and Fig. 2c). Sediment samples from the upper beach face at the Karrebæksminde barrier system consist of medium well sorted sand $\left(\mathrm{d}_{50}=1.1 \varphi-1.3 \varphi\right)$ at the Holsteinborg Nor barrier, and medium moderately well sorted sand $\left(\mathrm{d}_{50}=1.1 \varphi\right)$ at the Basnæs Nor barrier.

Faxe Bay, southeastern Sealand, is bordered by the limestone headland of Stevns Klint (Schou, 1949), and the chalk headland of the island of Møn in the south. Præstø Fjord is the bay head, closed off by the complex spit Feddet (Hede et al., in press; Bendixen et al., submitted) (Fig. 1, Box 2). A minor protruding cliff lies at Strandegård Dyrehave, about $5 \mathrm{~km}$ north of the accreting distal front of Feddet spit. At the distal accretional shore of Feddet, the beachface material is well sorted fine sand $\left(d_{50}=2.0 \varphi\right)$. The bathymetry of 
Faxe Bay shows a tunnel valley bending from an E-W orientation in the south of Præst $\varnothing$ Fjord toward N just east of Feddet spit. The tunnel valleys incises an otherwise mildly sloping shoreface (Fig. 2b and Fig. 2c).

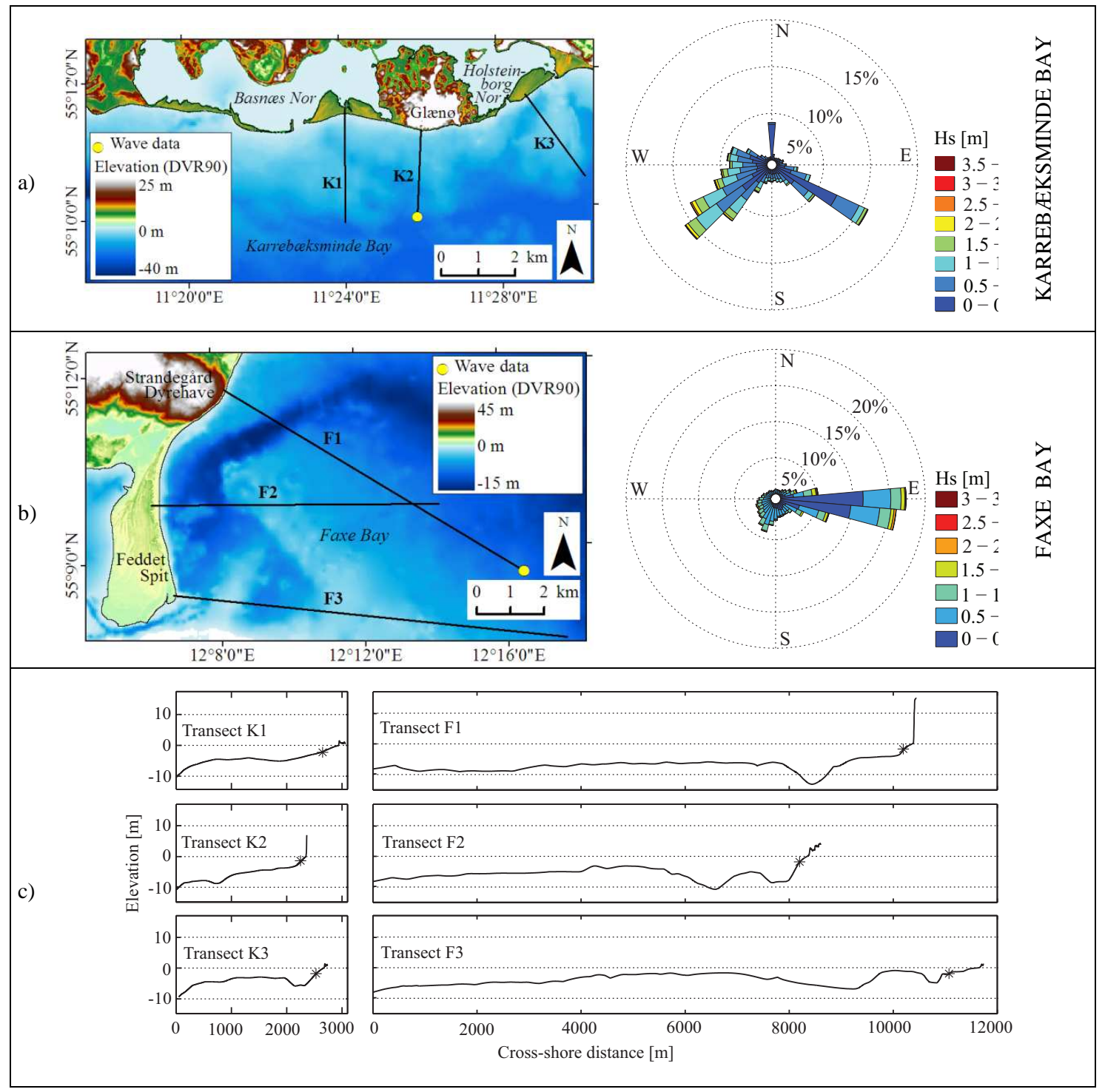

Figure 2: Maps of the study sites with indicated transect locations and related deep-water wave climate. a) Karrebæksminde Bay, b) Faxe Bay, c) Cross-shore profiles from deep-water wave locations shoreward, along transects indicated in Fig. 2a and Fig. 2b. Asterisks indicate locations of extracted transformed wave parameters

\subsection{Wind climate, wave climate and tidal range}

Wind measurements in Karrebæksminde Bay, ca. $15 \mathrm{~km} \mathrm{~W}$ of the island of Glæn $\varnothing$, show a bidirectional distribution of occurrence frequencies. The major peak from W / WSW (27\%) has an average wind speed of $8 \mathrm{~m} / \mathrm{s}$, the minor peak from ESE (10\%) has an average wind speed of $6 \mathrm{~m} / \mathrm{s}$ (Cappelen and Jørgensen, 1999). The fetch for wave generation is longest from SW (ca. $30 \mathrm{~km}$ ) and only little less from SE (ca. 20-25 km). Northerly winds are directed offshore in relation to the barrier front in Karrebæksminde Bay, and do not generate onshore propagating waves. The deep-water wave climate in Karrebæksminde Bay resembles the bidirectionality of the wind climate (Fig. 2a). 
Wind measurements in Faxe Bay, ca. $5 \mathrm{~km}$ SE of Feddet spit, indicate a bidirectional distribution of the frequency of occurrence. The major peak of occurrence from W (19\%) assembles only low and moderate wind speeds, with an average of $4 \mathrm{~m} / \mathrm{s}$. The highest wind speed class with an average of $6 \mathrm{~m} / \mathrm{s}$ is best represented from easterly directions (1\%) whereat the overall occurrence frequency of easterly winds is only $10 \%$ (Cappelen and Jørgensen, 1999). Westerly winds do not generate onshore propagating waves in Faxe Bay, while the stronger easterly winds propagate over a Baltic Sea fetch of nearly $100 \mathrm{~km}$, which is reflected in the wave climate as a pronounced peak in frequency of occurrence from easterly directions. Consequently, the deep-water wave climate in Faxe Bay is unidirectional (Fig. 2b).

The embayments are exposed to the same average wave energy levels. At both sites, the deep-water mean significant wave height $\left(\mathrm{H}_{\mathrm{s}}\right)$ is $0.4 \mathrm{~m}$ and the mean wave period $\left(\mathrm{T}_{02}\right)$ is $2 \mathrm{~s}$. However, the wave climates differ substantially in the directional distributions of dominant wave incidence: Karrebæksminde Bay is exposed to two dominant wave directions (Fig. 2a), whilst the deep-water wave climate in Faxe Bay is dominantly unidirectional (Fig. 2b). The mean spring tidal ranges in both Karrebæksminde Bay and Faxe Bay are $0.2 \mathrm{~m}$.

\section{Data \& Methods}

\subsection{Shoreline change quantification}

Multi-decadal shoreline changes were mapped based on topographic maps. Coastlines were digitized from raster datasets of scanned historical map sheets within ArcGIS. Vectorized shoreline positions allow the computation of shoreline change distances and rates and to identify their spatial variability. Shoreline changes were computed within the ArcGIS-based Digital Shoreline Analysis System (DSAS) by the US Geological Survey (Thieler et al., 2009) as described by Kabuth et al. (submitted) for a ca. 150 yr interval. The computation was based on orthogonal distances between shoreline positions identified on historical and modern topographic maps. DSAS computed the shoreline change distance as distance between shoreline intersections with cross-shore transects perpendicular to a baseline. Shoreline change rates were subsequently computed according to given survey dates. Supplementing information on shoreline positions at additional time steps between the framing years of the shoreline change computation were extracted from additional topographic maps and from aerial photographs.

\subsection{Aerial photographs and Digital Elevation Model (DEM)}

Aerial photographs (orthophotos from the year 1945 by I•GIS, Risskov, Denmark and orthophotos from the year 1995, by COWI A/S, Copenhagen, Denmark) were used to resolve the evolution of planform features within the multi-decadal time span. DEMs of bathymetry and topography were available from the Danish Maritime Safety Administration and from the National Survey and Cadaster of Denmark, respectively. The bathymetric DEM had a lateral resolution of $50 \mathrm{~m}$; the topographic DEM had a lateral resolution of $1.6 \mathrm{~m}$ and a vertical resolution of $0.01 \mathrm{~m}$ (Rosenkranz and Frederiksen, 2011). Beach ridges were identified on the topographic DEM. The orientation of beach ridges gave a qualitative indication of the historical shoreline orientation previous to periods documented in topographic maps and aerial photographs.

DEMs were also explored for a slope-based morphological shoreline classification. In a modified application of DSAS, the automated computation of distances between intersections of a pair of contour lines with DSAS cross-shore transects was used to determine the local terrain slope. Contour lines were extracted from the DEMs and the slope was derived from the computed distance between defined contour lines and the known elevation difference. This method was previously tested by Hansen (2012), on the island of Funen, Denmark. Kroon et al. (in press) identified cliff heights of around $5 \mathrm{~m}$ in eroding glacial bluffs on the Karrebæksminde barrier system. Contour intervals were adjusted from Hansen (2012) to detect cliffs in the barrier system: onshore slopes were detected between $0 \mathrm{~m}$ and $2.5 \mathrm{~m}$ elevation and between $2.5 \mathrm{~m}$ and $5 \mathrm{~m}$ elevation, respectively. Offshore slopes were computed between $-10 \mathrm{~m}$ and $-2.5 \mathrm{~m}$ elevation and between -2.5 $\mathrm{m}$ and $0 \mathrm{~m}$ elevation, respectively.

Shoreline changes reflected the mutual interaction of geomorphology with hydrodynamics. Multidecadal shoreline changes were quantified in a countrywide screening by Kabuth et al. (submitted). The 
screening allowed to highlight dynamic shores and the alongshore variability gave an indication of sediment sources and sinks. Onshore and offshore coastal slopes coupled the shoreline evolution with coastal exposure and could give an implicit indication of substrate characteristics. The slope-based morphological shoreline classification of the barrier fronts according to the modified methodology of Hansen (2012) allowed distinguishing cliff coasts, barrier coasts with flat strand plains and accretion in sheltered embayments for the onshore. Offshore, shoals and tunnel valleys incising the shoreface were detected. Based on the magnitude of multi-decadal shoreline changes and the slope-based morphological distinction, transect lines were defined for the study of wave energy transformation over cross-shore profiles.

\subsection{Wave transformation and directional energy fluxes}

5-years hindcast of deep-water wave climate for Karrebæksminde Bay and Faxe Bay (Fig. 2a and Fig. 2b) was used to determine wave energy fluxes at six coastal locations. Half-hourly MIKE $21 \mathrm{SW}$ hindcasts of $H_{s}, T_{02}$ and the mean wave direction $\theta$ were provided by the DHI Waterforecast for the years $2007-2011$. The crossshore profiles for wave propagation computations from ca. $-10 \mathrm{~m}$ to the beach were extracted from a merged grid of the topographic and bathymetric DEMs. A directional crop was applied to the overall deep-water wave climate to $+/-80^{\circ}$ around the shore normal at the landward end points of the cross-shore profiles.

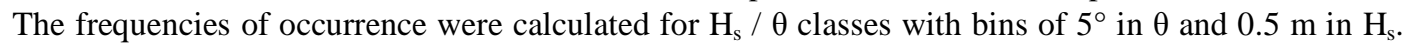
The mean $T_{02}$ was calculated for each $\mathrm{H}_{\mathrm{s}} / \theta$ class. A hydrodynamic model based on wave and roller energy balances (Grasmejer and Ruessink, 2003) was applied for the cross-shore wave transformation according to the computed occurrences of statistical wave parameters of the $5 \mathrm{yr}$ deep-water wave-climate. Cross-shore transformed wave parameters were extracted at the $-2 \mathrm{~m}$ contour line (asterisks in Fig. 2c) and the transformed total wave energy flux $P_{t o t}$ was estimated. This was just around the onset of wave breaking under average wave conditions in Faxe Bay and Karrebæksminde Bay. The total wave energy flux $P_{t o t}$ at the $-2 \mathrm{~m}$ contour line was decomposed for each governing $H_{s} / \theta$ class into alongshore and cross-shore directed vector components. The alongshore wave energy flux $P_{l}$ was defined as

$$
P_{l}=E \cdot c_{g} \cdot \sin \theta_{i} \cdot \cos \theta_{i}
$$

where $E$ is the wave energy, $c_{g}$ is the wave group velocity and $\theta_{i}$ is the angle of wave incidence relative to the cross-shore transect. The mean total wave energy flux $\overline{P_{t o t}}$ was computed from the weighted sum of all occurrences of $H_{s} / \theta$ classes. A normalized alongshore wave energy flux indicator $P_{l} / P_{\text {tot }}$ expressed the relative dominance of alongshore directed wave energy fluxes over the total wave energy flux. Theoretical values ranged from $P_{l} / P_{\text {tot }}=0$ for purely cross-shore directed wave energy fluxes to $P_{l} / P_{\text {tot }}=0.5$ for a maximum alongshore directed wave energy flux component at wave incidence angles of $\pm 45^{\circ}$ to the shore normal. For further characterization of the alongshore wave energy fluxes, we computed the net directionality of the alongshore wave energy component. In the computation of a location's total dimensionless alongshore wave energy flux $\sum P_{l} / \sum P_{t o t}, P_{l}$ was accounted for as sum of $P_{l}$ occurrences from both negative and positive wave incidence angles. These were expressed as $P_{l(-)}$ and $P_{l(+)}$, corresponding with wave incidence from the left and from the right of a transect, respectively, facing the shore. The net directionality of the alongshore wave energy fluxes $\operatorname{Dir}\left(P_{l}\right)$ was then defined as

$$
\operatorname{Dir}\left(P_{l}\right)=\sum\left|P_{l(-)}\right| / \Sigma\left|P_{l(+)}\right|
$$

with $\operatorname{Dir}\left(P_{l}\right)=1$ for equal levels of alongshore wave energy fluxes from both sides of a transect, and with $\operatorname{Dir}\left(P_{l}\right)>1$ and $\operatorname{Dir}\left(P_{l}\right)<1$ for dominant alongshore wave energy fluxes from the left and from the right of a transect, respectively.

\section{Results}

\subsection{Shoreline changes}

In Karrebæksminde Bay, inlet closure was coupled to barrier spit progradation toward opposing directions and a seaward pivoting of the barrier spit points. An onshore translation took place at the narrowest stretches of the central Basnæs Nor barrier islands, connected with inlet breaching (Fig. 5). The cross-shore translation was accompanied by erosion of protruding stretches. Accordingly, at recessed stretches along the barrier fronts, beach ridge plains prograded in cross-shore direction (Fig. 5). At the eastern Basnæs Nor barrier, beach ridges 
accreted parallel to their predecessors. Accretion at the western Basnæs Nor barrier was connected with inlet closure. The progradation around the recessed shores of the former inlet promoted the alignment of the barrier front combined with the erosion of adjacent protruding barrier stretches. At the eastern Holsteinborg Nor barrier, accretion rotated the former SSW-NNE oriented shoreline toward a SW-NE orientation (Fig. 5).

In Faxe Bay, the anchorpoint of Feddet spit was attached to the moraine ridge at Strandegård Dyrehave, a protruding cliff under erosion (Fig. 6). The protruding distal barrier front of Feddet spit however was prograding, whilst the northern shores were stable or slightly eroding. This resulted in shoreline rotation from a N-S orientation toward a NW-SE orientation. The embayed shores around the spit anchorpoint, adjacent to the eroding cliff coast, showed progradation (Fig. 6).

\subsection{Orientation of beach ridge systems}

A topographic DEM showed the orientation of beach ridge systems (Fig. 3). In Karrebæksminde Bay, the western barriers at Basnæs Nor (Fig. 3d) narrowed with recurved beach ridges indicating former spits. The two eastern barriers exhibited truncated NE and NW pointing beach ride systems, respectively. A southward prograding beach ridge system connected the two beach ridge systems (at transect K1, Fig.2a), closing a former inlet (Kroon et al., in press). A glacial bluff appeared just east of a NW pointing beach ridge system. At Holsteinborg Nor (Fig. 3e), the eastern barrier exhibited a truncated beach ridge system pointing toward NE. The youngest beach ridge attached to the NE pointing system in a more ENE pointing orientation, aligning with the adjacent mainland coast and the western part of the barrier.

In Faxe Bay, Feddet spit showed a progradation of southward pointing beach ridges (Fig. 3a). The system was truncated in the proximal part of Feddet spit. The youngest beach ridge system prograding at the distal spit aligned the shoreline in NW-SE orientation with the eroded proximal shores. Aerial photographs from the years 1945 and 1995 (Fig. 3b and Fig. 3c) showed a sand shoal providing the substrate for the recent distal progradation.
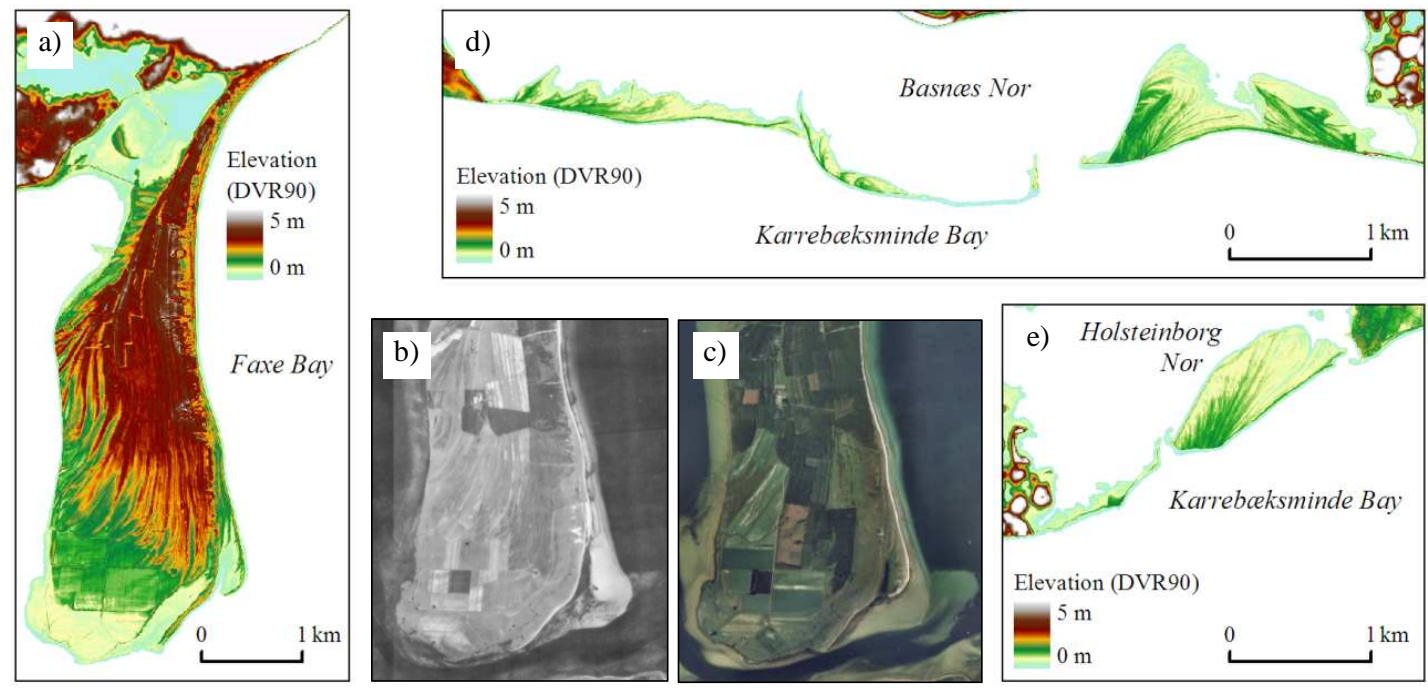

Figure 3: a) Topographic DEM of Feddet spit, b) aerial photograph of Feddet spit in 1945, c) aerial photograph of Feddet spit in 1995, d) DEM of Basnæs Nor barriers, Karrebæksminde Bay, e) DEM of Holsteinborg Nor barriers, Karrebæksminde Bay

\subsection{Slope-based morphological classification}

The classification of shores by their onshore and offshore slopes allowed a distinction with respect to the shores' exposure to wave incidence on one hand and with respect to their function as sediment source, on the other hand. The Karrebæksminde barrier system had a flat shoreface and a flat backshore with low crest heights and no dunes on the barrier islands. The intercepting moraine island of Glæn $\varnothing$ and a residual moraine ridge west of the island established steep glacial bluffs (Fig. 1a, Fig. 3b and Fig. 3c). Feddet spit had a very flat shoreface 
which was incised by a channel bending toward N-S orientation parallel to the proximal Feddet spit (Fig. 1b). At the distal, accreting barrier front, a sand shoal extended over about $1 \mathrm{~km}$ offshore (Fig. 3c). In the distal backshore was a beach ridge plain and the spit anchor point was connected to a steep glacial bluff in the north (Fig. 3a).

The computed onshore and offshore slopes for both embayments were placed in the classification scheme (Fig. 4). Erosive and stable shores identified in the computation of historical shoreline changes clustered around onshore $(0 \mathrm{~m}$ to $5 \mathrm{~m})$ slopes above $1 \times 10^{-1}$, and offshore $(-2.5 \mathrm{~m}$ to $0 \mathrm{~m})$ slopes above $9 \times 10^{-3}$. With regard to onshore slopes, this was in accordance with the flat / steep class boundaries suggested by Hansen (2012), but laid a magnitude lower for offshore slopes. The steep onshore - steep offshore class represented protruding cliff coasts, in the context of historical shoreline changes eroding or stable. Accretional and stable shores clustered in the flat slope classes, representing shores with moraine ridges in the hinterland of prograded marine deposits. The onshore slope defined by the $5 \mathrm{~m}$ contour line however represented recent and ancient cliff coasts, but not low barrier islands and spits.
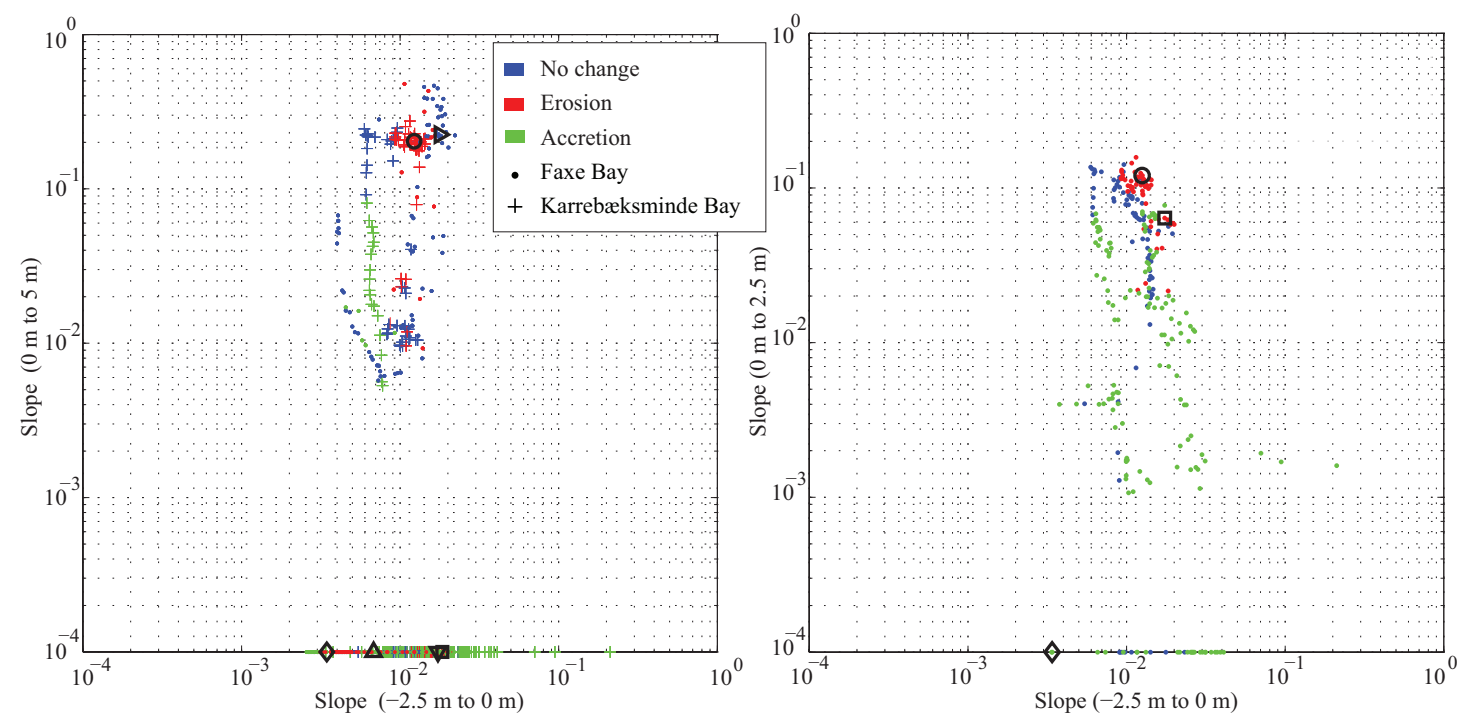

Figure 4: Slope-based morphological shoreline characterization Transect locations indicated by black symbols: $\mathrm{K} 2, \boldsymbol{\nabla}: \mathrm{K} 3, \mathrm{O}: \mathrm{F} 1, \square: \mathrm{F} 2, \diamond: \mathrm{F} 3$

In order to explore additional onshore slope variability, we related the $-2.5 \mathrm{~m}$ to $0 \mathrm{~m}$ offshore slope with the $0 \mathrm{~m}$ to $2.5 \mathrm{~m}$ onshore slope (Fig. 4). At Karrebæksminde Bay however, only cliffs reached elevations over $2.5 \mathrm{~m}$. The protruding barrier islands in the Karrebæksminde barrier system had crests below $0.5 \mathrm{~m}$ (Kroon et al., in press) and were not detected in the computation. Consequently, this slope computation characterized the barrier as the extent of elevations less than $2.5 \mathrm{~m}$, but failed to detect intra-barrier variability. Therefore, a modified elevation interval was tested with the $0 \mathrm{~m}$ and $1 \mathrm{~m}$ contour lines. Erosive and accretional coasts distributed randomly over the full range of coastal slopes.

The slope classification correlated with morphodynamic behavior at Faxe Bay, with regard to confined classes of erosion and wide ranges of slopes at accretional and stable shores. The beach slope had an effect on the cross-shore wave transformation. Erosive coasts clustered within narrow boundaries of $2 \times 10^{-2}$ to $2 \times 10^{-1}$ onshore slopes and $9 \times 10^{-3}$ and $2 \times 10^{-2}$ offshore slopes. Accretional coasts are wide spread over the range of flatter onshore slopes. Exclusively accretional and stable shores had offshore slopes lower than $8 \times 10^{-3}$ for all onshore slopes, and lower than $2 \times 10^{-2}$ onshore for all offshore slopes. Accreting marshes were detected.

\subsection{Wave energy fluxes}

At each study site, three cross-shore profiles were selected to represent both, erosive and accretional coasts, cliff coast, coastal plain and marshes, gently sloping shorefaces with and without incised channels and sand shoals attached to the shore. Besides, varying shoreline orientations were taken into account with respect to 
variations in wave incidence. Scott et al. (2011) identified the absolute wave power as a discriminating factor for the characterization of intermediate beach types, supplementary to the traditionally applied dimensionless morphodynamic parameters dimensionless wave height (Wright and Short, 1984) and relative tidal range (Masselink and Short, 1993). In Karrebæksminde Bay and Faxe Bay however, all beaches were situated with equal hydrodynamic parameters in the low-energetic field with negligible tidal range and thus prohibited a distinction by traditional morphodynamic parameters. We estimated for each location the directional distribution of the cross-shore transformed $P_{t o t}$ and $P_{l} / P_{\text {tot }}$ (Fig. 5 and Fig. 6), relating wave incidence with shoreline orientation. From these we derived the mean total wave power $\bar{P}_{\text {tot }}$ and the total dimensionless alongshore wave energy flux $\sum P_{l} / \sum P_{\text {tot }}$ (Table 1).

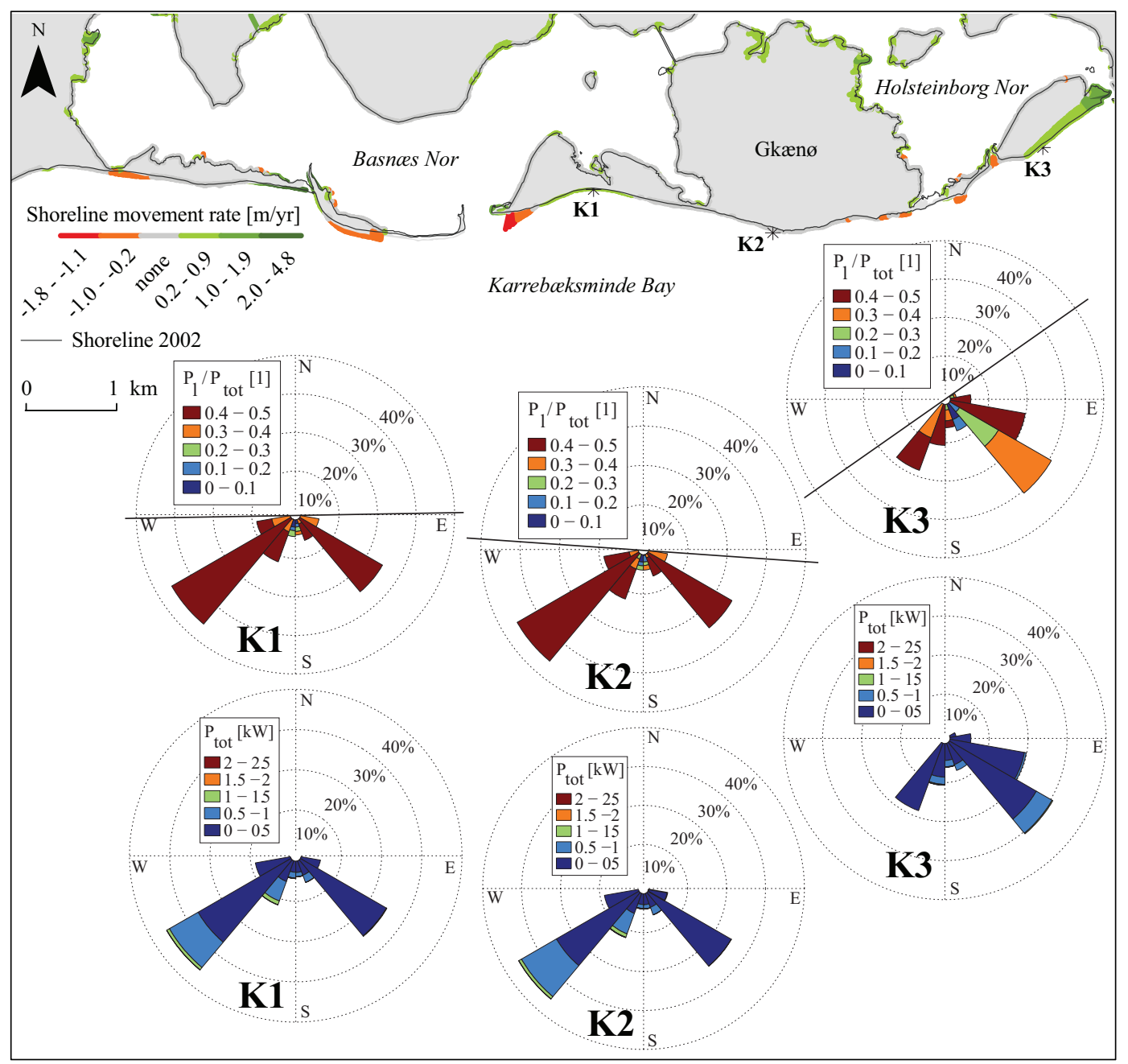

Figure 5: Shoreline change rates around the Karrebæksminde barrier system; transformed wave energy fluxes $P_{\text {tot }}$ and dimensionless alongshore wave energy fluxes $P_{l} / P_{\text {tot }}$ with related shoreline orientations (solid black lines); asterisks indicate locations of transformed waves for transect $\mathrm{K} 1, \mathrm{~K} 2$, and $\mathrm{K} 3$

The deep-water wave climate in Karrebæksminde Bay showed a bidirectional distribution, with about $25 \%$ of the wave incidence from SW and about $20 \%$ from SE. The incidence from the SW quadrant was widely spread around the SW peak and higher energy levels occurred more frequently (Fig. 2a). Wave transformation to shallow waters was performed over three cross-shore profiles: at transect $\mathrm{K} 1$ toward the prograding beach ridge plain at a former inlet, traversing a very flat, gently sloping shoreface; at transect $\mathrm{K} 2$ toward the cliff coast in the glacial deposits of the island of Glæn $\varnothing$; and at transect K3 toward the location of onset of shoreline rotating beach ridge accretion. The mean total wave power at all three transects in Karrebæksminde Bay was 
$\overline{P_{\text {tot }}}=0.2 \mathrm{~kW}$ (Table 1), and the dimensionless alongshore wave energy flux was $\sum P_{l} / \sum P_{\text {tot }}=0.4$. However, only the two western locations, at transects $\mathrm{K} 1$ and $\mathrm{K} 2$, experienced pronounced directionality of the alongshore wave energy flux from W. For the easternmost transect K3, Fig. 5 showed the highest occurrence frequency from SE, but a more pronounced dimensionless alongshore wave energy flux from SW. The major peak in occurrence of transformed wave direction coincided with the shore normal, resulting in little alongshore directed wave energy flux. The minor peak in occurrence of transformed wave direction drew an acute angle with the shoreline, enhancing the alongshore component. This was reflected in an indistinct net alongshore directionality, with only a weak dominance from W (Table 1). The net directionality of alongshore wave energy fluxes from $\mathrm{W}$ was much more pronounced at transects $\mathrm{K} 1$ and $\mathrm{K} 2$ (Table 1), where high occurrence frequencies, higher energy levels and enhanced alongshore wave energy fluxes coincided (Fig. 5). Here, the major westerly peak in deep-water occurrence frequencies was less affected by refraction.

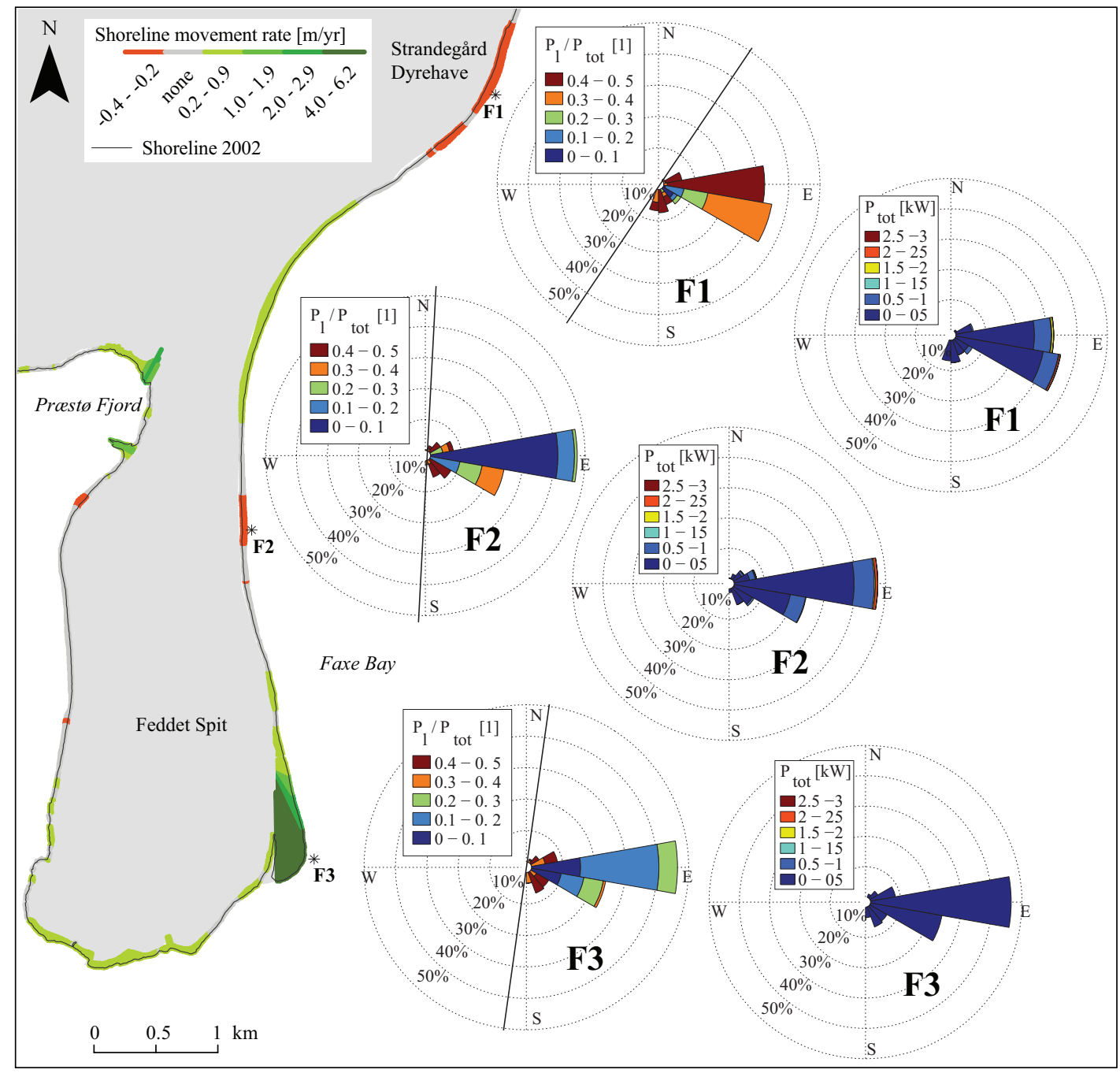

Figure 6: Shoreline change rates around Feddet Spit; transformed wave energy fluxes $P_{t o t}$ and dimensionless alongshore wave energy fluxes $P_{l} / P_{\text {tot }}$ with related shoreline orientations (solid black lines); asterisks indicate locations of transformed waves for transect F1, F2, and F3

A unidirectional distribution characterized the deep-water wave climate in Faxe Bay, with about 35\% of the wave incidence from E and ESE (Fig. 2b). The deep-water wave climate was transformed over three cross-shore profiles: at transect F1 toward the erosive convex cliff coast in the glacial deposits at Strandegård Dyrehave, traversing an incised channel (trough ca. $1.9 \mathrm{~km}$ offshore); at transect $\mathrm{F} 2$ toward the eroding 
proximal beach ridge plain at a straight N-S oriented shore of Feddet spit, where the incised channel was closest to the coast (trough $0.7 \mathrm{~km}$ offshore); and at transect F3 toward the distal rotating shore with the highest progradation rates along Feddet spit, traversing a sand shoal adjacent to the coast. The mean total wave power for all three transects in Faxe Bay varied only slightly within in the low-energetic range, from $\overline{P_{\text {tot }}}=0.2 \mathrm{~kW}$ at the two northern locations to $\overline{P_{t o t}}=0.1 \mathrm{~kW}$ at the southern location (Table 1). The total dimensionless alongshore wave energy flux decreased from $\sum P_{l} / \sum P_{\text {tot }}=0.3$ in the north to $\sum P_{l} / \sum P_{\text {tot }}=0.2$ at the two southern locations. The alongshore wave energy flux component had a pronounced net direction from $\mathrm{N}$ at the northernmost transect F1 (Table 1). At transects F2 and F3, the magnitude of the alongshore wave energy flux was low with the net direction from $\mathrm{S}$ at transect $\mathrm{F} 2$ and from $\mathrm{N}$ at transect F3. However, the net directionality was not important at the two latter locations, as cross-shore wave energy fluxes dominated (Table 1 and Fig. 6). The transformed directional waver power distribution showed at transect F1 that refraction focused the dominant direction of wave incidence at ESE directions, yet maintaining a pronounced alongshore component from E toward the SW-NE oriented shoreline (Table 1 and Fig. 6). At transects F2 and F3, the component of alongshore wave energy fluxes decreased as the shoreline orientation aligned perpendicular to the dominant direction of wave incidence. At the distal accretional shore around transect F3, wave energy was dissipated over shoals, reducing the incident wave power by about $50 \%$ compared to the incident wave power at the erosive shores around transect location F2.

Table 1: Wave climate at $-2 \mathrm{~m}$ in Karrebæksminde Bay and Faxe Bay

\begin{tabular}{|c|c|c|c|c|c|c|c|}
\hline & $\begin{array}{c}\overline{P_{t o t}} \\
{[\mathrm{~kW}]}\end{array}$ & $\begin{array}{c}\operatorname{Dir}\left(P_{l}\right) \\
{[1]}\end{array}$ & $\begin{array}{c}\sum P_{l} / \sum P_{t o t} \\
{[1]}\end{array}$ & & $\begin{array}{l}\overline{P_{t o t}} \\
{[\mathrm{~kW}]}\end{array}$ & $\begin{array}{c}\operatorname{Dir}\left(P_{l}\right) \\
{[1]}\end{array}$ & $\begin{array}{c}\sum P_{l} / \sum P_{t o t} \\
{[1]}\end{array}$ \\
\hline K1 & 0.2 & $3.5(\mathrm{~W})$ & 0.4 & F1 & 0.2 & $0.2(\mathrm{~N})$ & 0.3 \\
\hline K2 & 0.2 & $3.6(\mathrm{~W})$ & 0.4 & F2 & 0.2 & $1.2(\mathrm{~S})$ & 0.2 \\
\hline K3 & 0.2 & $1.2(\mathrm{~W})$ & 0.4 & F3 & 0.1 & $0.8(\mathrm{~N})$ & 0.2 \\
\hline
\end{tabular}

\section{Discussion}

Shoreline changes in Karrebæksminde Bay showed erosion of protruding barrier stretches, and progradation at recessed shores, both cross-shore directed and shoreline-rotating. The observed combined effect of shoreline changes on the barrier morphology was an alignment of the barrier front. Accordingly in Faxe Bay, Feddet Spit showed accretion at recessed stretches adjacent to eroding cliff coasts. The protruding distal barrier front in contrast prograded, with the effect of shoreline rotation. In beach ridge systems of the Karrebæksminde barrier system we identified alternating directions of progradation, with subsequent truncation of the former anchor points. The truncated beach ridge systems framed historical locations of inlets (Kroon et al., in press). The converging orientation of the residual beach ridges indicated former sediment sources toward their anchor points, eroded during the evolution of the barrier system.

We examined the impact of coastal slopes and wave incidence on shoreline evolution. The slopebased morphological shoreline characterization allowed a rough distinction between exposed coastal cliffs in moraine deposits and hinterland elevation of moraine ridges behind a coastal plain. Very flat young prograding shores were distinguished at Feddet spit. However, in Karrebæksminde Bay the very low crested barriers allowed only the distinction of coastal cliffs in glacial deposits and barrier islands. A tested modification of the upper beach slope contour line to $1 \mathrm{~m}$ did not result in discernible patterns of protruding coasts under erosion and accreting recessed coasts.

The bidirectional deep-water wave climate in Karrebæksminde Bay promoted strong dimensionless alongshore wave energy fluxes with a pronounced net direction from $\mathrm{W}$ at transects K1 and K2. Supported by tracing of beach ridge systems on a DTM and the computation of historical shoreline changes, this suggests the eroding former headland at the east bank of the recent inlet as a sediment source for the cross-shore progradation at $\mathrm{K} 2$. The same magnitude of dimensionless alongshore wave energy fluxes at transect $\mathrm{K} 3$ resulted in weak net directionality, due to the bidirectional distribution of wave incidence. The stronger pronounced deep-water peak in occurrence frequencies was here diminished by refraction. The dimensionless alongshore wave energy flux could thus be deceptive in multi-directional wave climate with regard to the net direction of energy fluxes. Kroon et al. (in press) pointed out the importance of storm surges for the evolution 
of the barrier system in terms of inlet breaching. The sensitivity of the directional distribution of incident wave energy fluxes to changes in the shoreline orientation could indicate an interaction of protruding coastal stretches and a gradual reorientation of the shoreline orientation under average wave conditions.

Faxe Bay showed low dimensionless alongshore wave energy fluxes at all locations. The net direction of the alongshore directed wave energy fluxes was from $\mathrm{N}$ at the cliff (transect $\mathrm{F} 1$ ) and from $\mathrm{S}$ at the proximal erosive shore (transect F2). This contradicted the assumption that accretion at Feddet spit was fed by sediment from adjacent glacial bluffs in the north or from the cliff of Stevns Klint (Schou, 1945). Rather, wave energy dissipation over the sand shoal and the dominance of cross-shore directed wave energy fluxes indicated that distal accretion at Feddet spit was fed by cross-shore sediment fluxes.

\section{Conclusions}

We combined visual interpretation of DEMs and aerial photographs with quantitative approaches to shoreline changes and wave energy fluxes to understand the governing processes in barrier and spit evolution in two lowenergy, micro-tidal embayments in Denmark.

Beach ridge orientations and shoreline change patterns in Karrebæksminde Bay indicated erosion of formerly protruding headlands as sediment sources. In combination with a subsequent shoreline rotation through beach ridge accretion this would have contributed to an alignment of the barrier coastlines. The rotational progradation orientated the shoreline toward an equilibrated impact of both peaks in the deep-water wave directions. In Karrebæksminde Bay, the shoreline orientation seemed to explain the variability in shoreline evolution rather than the actual coastal slope on the narrow, low-crested barriers.

The interaction of wave incidence with shoreline orientation showed that in a bidirectional wave climate the directional decomposition of the alongshore wave energy flux was important. With respect to sediment transport, the total dimensionless alongshore wave energy flux would overestimate the importance of littoral drift, if multiple alongshore directed components canceled each other out. In the unidirectional wave climate of Faxe Bay however, the magnitude of the net directionality of alongshore wave energy fluxes followed the magnitude of the total dimensionless alongshore wave energy flux.

In combination, the total dimensionless alongshore wave energy flux and its net directionality could give indications of associated sediment sources and sinks.

\section{Acknowledgements}

This work has been supported by the Danish Council for Strategic Research (DSF) under the project Danish Coasts and Climate Adaptation - flooding risk and coastal protection (COADAPT), project no. 09-066869. Hindcast wave data have been provided by the Water Forecast / DHI. Vagn Moser at the Department of Geosciences and Natural Resource Management, University of Copenhagen, is thanked for the grain size analysis.

\section{References}

Anthony, E.J., 1998: Sediment-Wave Parametric Characterization of Beaches. Journal of Coastal Research, 14 (1): $347-$ 352.

Bendixen, M., Clemmensen, L.B. and Kroon, A., submitted: Berm and beach ridge formation in relation to extreme sealevels: a Danish example in a microtidal environment. Marine Geology.

Bruun, P., 1946: Ligevægtsformer for Materialvandringskyster, Geografisk Tidsskrift, 48: 27-71. (in Danish with English summary)

Brøndum, P., 1972: Coastal Morphology of Basnæs Nor and the Surrounding Waters, Geografisk Tidsskrift, 71: 20-36.

Cappelen, J. and Jørgensen, B., 1999: Observed Wind Speed and Direction in Denmark - with Climatological Standard Normals, 1961-90, Technical Report, 99-13, Danish Meteorological Institute, Copenhagen, Denmark.

Christiansen, C., Møller, J.T., Nielsen, J., 1985: Fluctuation in sea-level and associated morphological response: Examples from Denmark, Eiszeitalter und Gegenwart, 35: 89-108. 
Christiansen, S., 1958: Bølgekraft og kystretning. Eksempel på kystudformning i Det Sydfynske Øhav. Geografisk Tidsskrift, 57: 23-37. (in Danish with English summary)

Grasmeijer, B.T., Ruessink, B.G., 2003: Modeling of waves and currents in the nearshore parametric vs. probabilistic approach. Coastal Engineering, 49: 185-207.

Hansen, L., 2012, Classification of coastal types - Based on ArcGIS and the Digital Shoreline Analysis System, Unpublished M.Sc.Thesis, University of Copenhagen, Denmark.

Hede, M., Nielsen, L., Clemmensen, L., Kroon, A., Bendixen, M., in press: On the validity of sea-level markers identified in ground-penetrating radar data collected across microtidal beach deposits. The Holocene.

Hegge, B., Elliott, I., Hsu, J., 1996: Sheltered Sandy Beaches of Southwestern Australia. Journal of Coastal Research, 12 (3): 748-760.

Kabuth, A., Kroon, A.K., Pedersen, J.B.T., submitted: Multi-decadal shoreline changes in Denmark. Geomorphology.

Kroon, A., Kabuth, A.K., Westh, S., in press: Morphologic evolution of a storm surge barrier system. Journal of Coastal Research.

Krüger, J., 1969: Landskabsformer i sydlige Sjælland. Studier over glaciallandskabets morfologi, opbygning og dannelse.Geografisk Tidsskrift, 68: 105-212. (in Danish with English summary)

Masselink, G. and Short, A.D., 1993: The effect of tide range on beach morphodynamics and morphology: A conceptual beach model. Journal of Coastal Research, 9 (3): 785-800.

Rosenkranz, B., Frederiksen, P., 2011: Quality assessment of the Danish Elevation Model (DK-DEM), National Survey and Cadastre - Denmark, technical report series no. 12.

Scott, T., Masselink, G., Russel, P., 2011: Morphodynamic characteristics and classification of beaches in England and Wales. Marine Geology, 286: 1-20.

Schou, A., 1949: Danish coastal cliffs in glacial deposits, Geografiska Annaler, 31: 357-364.

Schou, A., 1945: Det Marine Forland. Folia Geographica Danica, Tome IV.

Støttrup, J.G., 1999: Kortlægning af stenrev, stenfiskeri og fiskeri på hårdbund samt metoder til videnskabelige unders $\emptyset$ gelser af rev og hårdbund. DFU-report no.63-99. (in Danish with English summary)

Westh, S., 2012: Barriereudvikling i et stormflods domineret miljø. Unpublished M.Sc. Thesis, University of Copenhagen, Denmark. (in Danish)

Wright, L.D., and Short, A.D., 1984: Morphodynamic variability of surf zones and beaches: A synthesis. Marine Geology, 56: $93-118$. 